\title{
OBTAINING HYSTERESIS LOOPS AT LOW FREQUENCY FOR CHARACTERIZATION OF MATERIALS TO BE USED IN BIOMEDICAL APPLICATIONS
}

\author{
Atika Arshad, Rumana TaSnim, Sheroz Khan And AHM Zahirul Alam
}

Electrical and Computer Engineering Department, International Islamic University Malaysia, Jalan Gombak, 53100, Kuala Lumpur, Malaysia.

atikaarshad@hotmail.com

(Received 19 May 2013; accepted 12 March 2015; published on line 29 May 2015)

\begin{abstract}
The promising development of magnetic sensors in the biomedical field demands an appropriate level of understanding of the magnetic properties of the materials used in their fabrication. To date some types of magnetic materials are encountered where their magnetic properties, characterization techniques and magnetization behavior are yet to be explored more suitably in light of their applications. This work studies the characterization of such materials by using a cost effective and simple circuit consisting of inductive transducer and an OP-AMP as a voltage integrator. In this approach the circuit was simulated using PSPICE and experiments have been conducted to achieve the desired results. The simulation and experimental results are obtained for three test materials namely iron, steel and plastic. The novelty lies in applying the simple circuit for material testing and characterization via obtaining simulation results and validating these results through experiment. The magnetic properties in low external magnetic field are studied with materials under test. The magnetization effect of a magneto-inductive sensor is detected in the low frequency range for different magnetic core materials. The results have showed changes in magnetization behavior of magnetic materials due to the variation of permeability and magnetism. The resulting hysteresis loops appear to have different shapes for different materials. The magnetic hysteresis loop found for an iron core demonstrated a bigger coercive force and larger reversals of magnetism than those of a steel core, thus obtaining its magnetic saturation at a larger magnetic field strength. The shape of the hysteresis loop itself is found to be varying upon the nature of the material in use. The resulting magnetization behaviors of the materials show their possible applicability for use in sensing devices. The key concern of this work is found upon selecting the appropriate magnetic materials at the desired frequency of operation for magneto resistive applications, magneto-resistive sensors and for an extensive range of biomedical sensor application.
\end{abstract}

ABSTRAK: Kemajuan penderia bermagnet yang menggalakkan dalam bidang bioperubatan memerlukan peringkat pemahaman yang tertentu bagi memahami ciri-ciri bermagnet bahan yang digunakan dalam fabrikasi. Kini, hanya terdapat beberapa jenis bahan bermagnet yang ditemui; di mana sifat-sifat bermagnet, teknik pencirian dan kelakuan pemagnetan masih belum dikaji agar sesuai di gunakan untuk aplikasi yang sepatutnya. Analisa ini mengkaji ciri-ciri bahan dengan menggunakan litar yang mudah dan berkesanan kos yang terdiri daripada aruhan pentransduksi dan OP-AMP sebagai integrasi voltan. Litar disimulasi menggunakan PSPICE dan eksperimen dijalankan untuk mendapatkan keputusan yang diingini. Keputusan simulasi dan eksperimen 
diperolehi dengan menggunakan bahan uji besi, keluli dan plastik. Menariknya, litar yang mudah digunakan untuk kajian bahan dan penciriannya diperolehi menggunakan keputusan simulasi dan keputusan tersebut disahkan dengan eksperimen. Sifat-sifat bermagnet pada medan magnet luaran rendah dikaji dengan bahan-bahan uji kaji. Kesan pemagnetan daripada penderia induktif-magneto dikesan dalam linkungan frekuensi yang rendah untuk bahan teras magnet yang berbeza. Keputusan menunjukkan sifat pemagnetan bahan magnet disebabkan oleh perbezaan kemagnetan dan kebolehtelapan. Keputusan gelung histerisis didapati menghasilkan bentuk yang berbeza untuk bahan yang berbeza. Gelung histerisis magnetik yang terdapat pada teras besi memberikan daya paksa dan kemagnetan berbalik yang lebih besar berbanding dengan teras keluli; jesteru memberikan magnetik tepu pada kekuatan medan magnet yang lebih besar. Bentuk gelung histerisis juga berbeza bergantung kepada keadaan bahan yang digunakan. Sifat pemagnetan yang terhasil menunjukkan berkebolehgunaan bahan-bahan tersebut sebagai alat penderia. Matlamat utama pengkajian ini adalah untuk memilih bahan magnetik yang sesuai pada frekuensi yang diinginkan untuk tujuan aplikasi rintangan megneto, penderia rintangan-magneto dan aplikasi skop penderia bioperubatan yang ekstensif.

KEYWORDS: hysteresis loop; characterization; magnetization

\section{INTRODUCTION}

Understanding the properties of magnetic materials is very important for their applications in device fabrication used in parameter sensing and knowing the function of electronic devices. An added reason for this understanding also comes from the particular fact that magnetic materials over the last twenty years have changed dramatically both in terms of their applications and in the amount of their use. Traditionally, magnetic materials have found applications in mechanical systems making use of heavy current circuits, but in recent years, new and improved materials with magnetic properties have been developed for use in consumer electronics such as gadgets, toys and handheld electronic devices available in the market, leading to finding applications never imaginable a few years ago. The development of various sensors has opened up several possibilities for significant improvements in the advancement of bio-implantable devices or medical equipment. Hence many problems regarding the magnetic properties of magnetic materials need to be examined from the elementary point of view. To select a magnetic material necessitates complete familiarity with the material's magnetic properties. This warrants a renewed attention and research interest required for proper investigation on characterization of magnetic materials.

Magnetic materials can be used in fields such as magnetic sensing circuitry for cell separation, immunoassays, magnetic resonance imaging (MRI), drug and gene delivery, minimally invasive surgery, radionuclide therapy, hyperthermia, and artificial muscle application. Among the physical properties that make magnetic materials appropriate for biomedical applications is that these materials can be manipulated by an external magnetic field, which is useful in hyperthermia applications. However, not all magnetic materials have similar magnetic properties. Characterization is vital in order to put emphasis on the appropriate applicability of magnetic materials. This research is an attempt at characterizing magnetic materials through analyzing the magnetization behavior in low frequencies for biomedical applications.

The idea of using various sensors in magnetic field system applications was first put forward by Mokwa [1] and Ben et al. [2]. This also allowed the possibility of simple device fabrication. A work reported by [3] demonstrates the use of magnetic materials for a biomedical application. The delivery of drugs using nano-particles (as shown in Fig. 1) 
is carried out by encapsulating the magnetic material to ensure its biocompatibity, then by means of an applied magnetic field, the magnetic nanoparticles can then have the possibility of being led towards a specific target in the human body. The applied magnetic field has to be very low. Suitable materials used in this case are those with high magnetization at the operation temperature (magnetic iron oxide). Thus the relative amount of this material and its material properties should be taken into consideration.

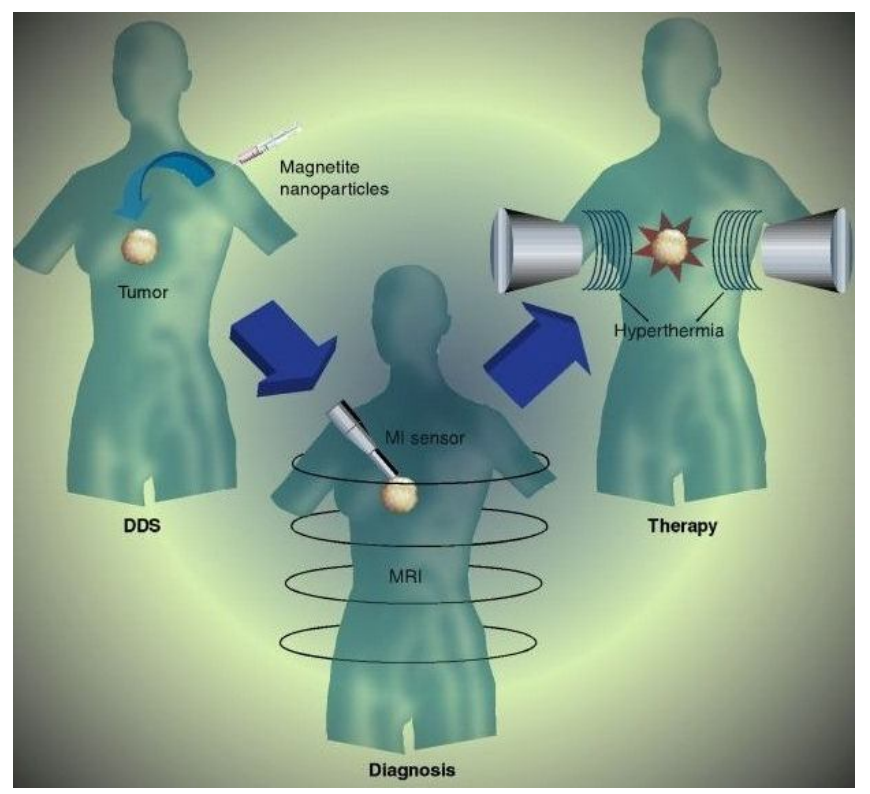

Fig. 1 Therapeutic strategy using magnetic nano-particles [3].

In [4], the author designed a tongue drive system for enabling a person with severe disabilities. It predicts the users' intentions by wirelessly tracking the movements of a permanent magnetic tracer that are secured on their tongues using an array of magnetic sensors (see Fig. 2). Comprehensive research work [5-8] has shown increasing interest on numerous magnetic materials used in biomedical applications.

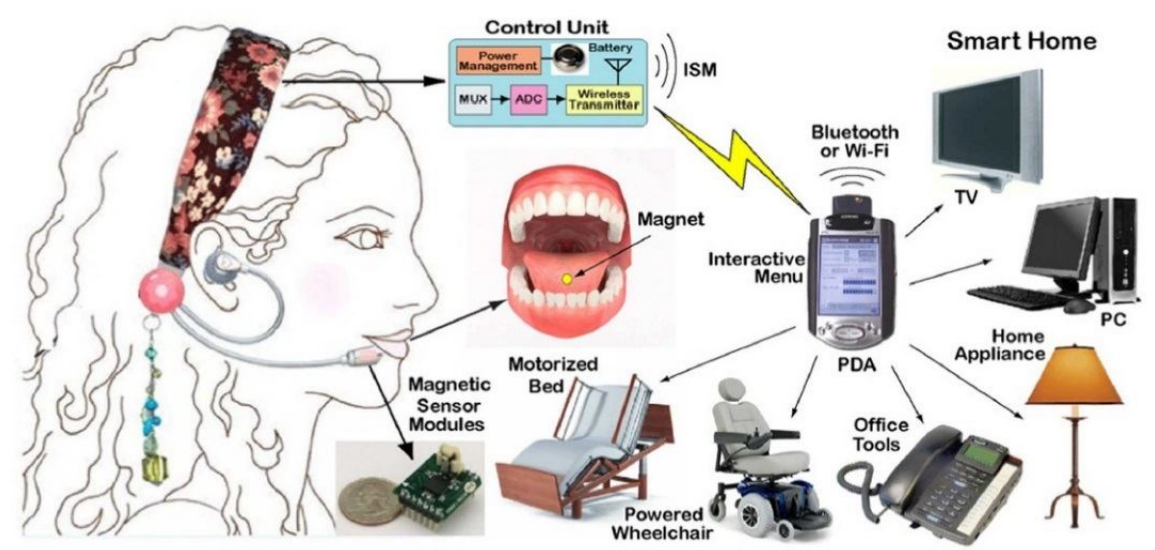

Fig. 2 Block diagram of tongue-computer interface system, based on wireless magnetoinductive sensor [4]. 
This work applies an inductive transducer to investigate magnetic and non-magnetic materials under low frequency. The aim of the proposed work is to identify the material to be used as the inductive sensory system, eventually identifying materials for sensors fabrication. The materials are distinguished by achieving unique hysteresis loops. The procedure adopted is in the form of a suitably selected circuit. Simulation results are obtained using PSPICE. The simulation work is also validated via experiments. This work will be able to characterize magnetic and non-magnetic materials for biomedical applications, which require low frequencies

\section{INTRODUCTION TO MAGNETIC HYSTERESIS FOR CHARACTERIZATION OF MATERIALS}

One of the key features of magnetic fields is that they are not affected by the presence of any external element such as (soil, water, or air). This effect enhances the material suitability to be used as sensors [9]. A magnetic sensor carries out the measurement of physical properties (such as pressure, temperature, and flow), as well as the detection of any type of change that occurs in magnetic field. Thus the understanding of the characteristic properties of magnetic core materials will enable the readers to know the response of the sensors. In general, these magnetic materials are classified into two types: soft and hard magnetic materials. Soft magnetic materials can be easily magnetized and demagnetized while the hard magnetic materials cannot be demagnetized so easily, since they retain their magnetism. Usually ferromagnetic materials are magnetized easily; in strong magnetic fields the magnetization approaches a certain limit called saturation. With sudden application of a field and its removal, magnetization does not return to its original value - this is denoted as hysteresis. For a ferromagnetic core material, the hysteresis loop is plotted between the magnetizing intensity, $\mathrm{H}$, on the horizontal axis and the magnetic flux density, B, on the vertical axis. In order to trace the shape of the hysteretic loop for magnetic materials, many experiments have been conducted. An instance demonstrating the hysteretic behavior is shown in Fig. 3.

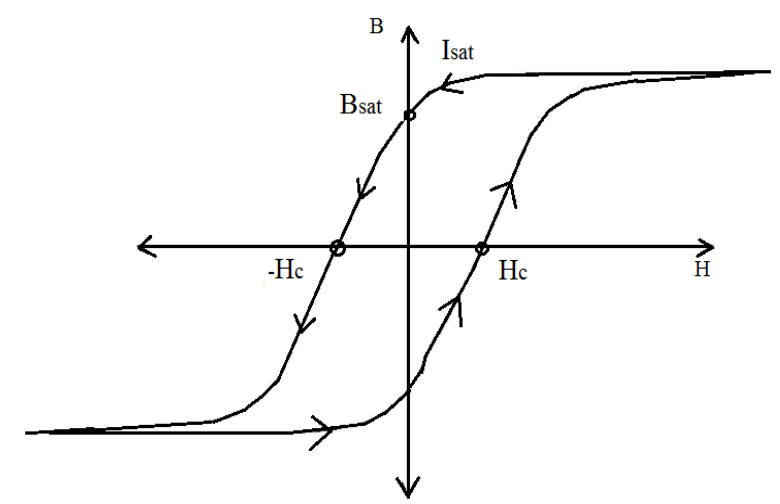

Fig. 3 Hysteresis loop of magnetic material [10].

The shape of the B-H curve is different for different core materials. Also, the rate of change in the magnetic field affects the B-H curve shape. In accordance with the field strength, flux density keeps increasing until it arrives at a specific value where it stops increasing and becomes almost constant since the field strength keeps on raising to the 
amount of flux density that can be produced by the core. Flux density increases in proportion to the field strength until it reaches a certain value where it cannot increase anymore and becomes almost level and constant as the field strength continues to increase due to a certain limit to the amount of flux density that can be generated by the core. Any further increase will have no effect on the value of $\mathrm{B}$, and the point on the graph where the flux density reaches its limit is referred as magnetic saturation, which is also identified as saturation of the core. By changing the direction of the magnetizing current constantly through the coil from a positive direction to a negative direction, the magnetic hysteresis loop of the ferromagnetic core can be produced [10]. The appropriate selection and processing of magnetic core materials determines the magnetic performance level. Some researchers have applied techniques which have been developed to analyze the magnetic hysteresis loop and magnetization process (the properties of the magnetic materials which might affect the sensors responses).

\section{HYSTERESIS LOOPS CIRCUIT MODEL}

The hysteresis loop setup for characterization of materials is designed by using the diagram illustrated in Fig. 4. The setup is an integration of two parts; the coil setup and the op-amp integrator. The coil setup is a magneto-inductive coupling circuit consisting of primary and secondary windings, which allows wireless transfer of signals across narrow gaps. The internal distance between the coils has an effect on the strength of signal transmission. The op-amp integrator circuit in the diagram (as in Fig. 4) is connected to the secondary circuit of the coil, thus the output of the transformer coil becomes the input of the op-amp, and hence the output voltage waveform of the op-amp responds to the changes in the input voltage waveform. The integrator amplifier acts as a storage element, which produces a voltage output that is proportional to the integral of its input voltage with respect to time.

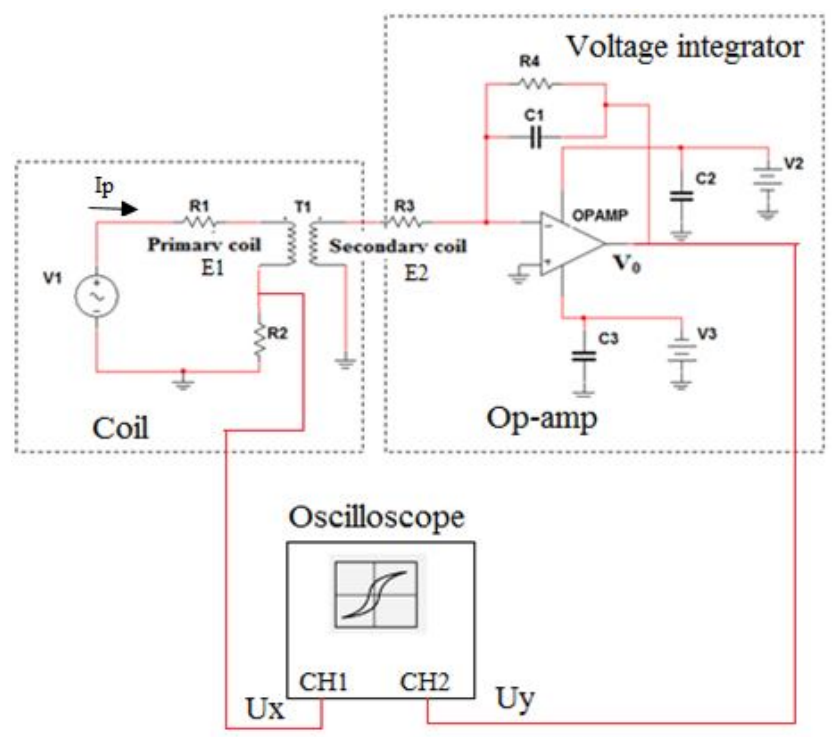

Fig. 4 Hysteresis circuit setup for characterization of materials.

In Fig. 4, primary coil $\left(\mathrm{N}_{1}\right)$ and secondary coil $\left(\mathrm{N}_{2}\right)$ are the magnetization coils of the test samples and turn of the measuring coil. An AC sinusoidal signal is injected into the excitation winding / primary coil, which induces a magnetic field $\mathrm{H}$ in the test sample. 
$\mathrm{R}_{1}$ is the resistor which limits the current flow to the test sample primary coil loop while $\mathrm{R}_{2}$ is the shunt resistor. The value of current $I_{P}$ (current in the primary loop) is obtained by measuring the voltage drop across the shunt resistor. Hence, the value of applied magnetic field $\mathrm{H}$ is directly proportional to the current and this is represented by the following formula:

$$
U_{X}=i_{p} R_{2}=l H R_{2} / N_{1}
$$

Hence,

$$
H=\frac{N_{1}}{l} I
$$

The applied magnetic field in the excitation coil / primary coil gives rise to an induced voltage $e_{2}$ across the secondary coil. The relation between the induced voltage $e_{2}$ and magnetic induction intensity $B$ is given by:

$$
e_{2}=N_{2} A d B / d t
$$

Hence,

$$
B=\frac{\phi}{N_{2} A}
$$

where,

$\mathrm{H}=$ Magnetic field strength in $[\mathrm{A} / \mathrm{m}]$

$\mathrm{B}=$ Flux density $[\mathrm{T}]$

$\mathrm{N}_{1}=$ Total number of turns in the primary coil

$\mathrm{N}_{2}=$ Total number of turns in the secondary coil.

$l=$ Length of the test material $[\mathrm{m}]$

$I=$ Magnetizing current $[\mathrm{A}]$

$\phi=$ Magnetic flux $[\mathrm{Wb}]$

$\mathrm{A}=$ Cross sectional area of the sample magnetic material $\left[\mathrm{m}^{2}\right]$

The operational amplifier is connected to the secondary winding that is used as a voltage integrator. The capacitors $C_{1}$ and $C_{2}$ were selected as $1 \mu F$ and $100 \mathrm{nF}$ respectively. The output of the operational amplifier is derived as:

$$
\begin{aligned}
& V_{0}=U_{y}=-\frac{1}{R_{3} C_{1}} \int_{0}^{t} V_{s} d t \\
& U_{y}=-\frac{1}{R_{3} C_{1}} \int_{0}^{t}-e_{2} d t=B N_{2} A / R_{3} C_{1}
\end{aligned}
$$

where the value of $R C>>1 / 2 \pi f$.

By using Eq.3 and Eq.1, the value of B and $\mathrm{H}$ can be obtained respectively. Thus, Uy and $\mathrm{Ux}$ are said to be proportional to $\mathrm{B}$ and $\mathrm{H}$, which are the horizontal and vertical inputs.

The physical dimension of coils in the circuit, the distance between the two coils and the permeability of the cores, the number of turns in each coil [11] etc. are related to the mutual inductance. The mutual inductance between two coils, $L_{1}$ and $L_{2}$, can be written in term of the inductance of each coil and the coupling coefficient, $k$. The formula is written as: 


$$
\begin{aligned}
& k=\frac{M}{\sqrt{L_{1} L_{2}}} \\
& L=\mu \frac{N^{2} A}{l}
\end{aligned}
$$

Where $\mathrm{N}$ is the number of turns per unit length of the coil of length $l, \mathrm{~A}$ is the crosssectional area of core, and $\mu$ is the permeability of the core.

Thus, $\mu=\mu_{0} \mu_{r}=B / \mathrm{H} \mathrm{Hm}^{-1}$

\section{RESULTS ANALYSIS AND DISCUSSION}

This work demonstrates the use of a simple circuit for material testing and characterization via obtaining simulation results and validating these results through experiments. The proposed circuit model was simulated using PSPICE and experiments were conducted to achieve the desired results. The simulation and experimental results are obtained for three test materials namely iron, steel and plastic.

\subsection{Simulation Analysis to Obtain B-H Loops}

In PSPICE simulation the effect of changing core materials is modelled through selecting relevant values of the coupling coefficient representing core materials of iron, steel and plastic. The relationship between $k$ and $\mu$ is such that, $k$ is inversely proportional to the square root of the product of self-inductance, that is $k=\sqrt{L_{1} L_{2}}$, and the inductance, $L=\mu \frac{N^{2} A}{l}$ is influenced by the permeability of the material. Henceforth, it can be said that the change in the material's permeability is represented by the change in the coupling coefficient factor.

The coupling coefficient determines the strength of magnetic coupling between two coils. The coupling coefficient is considered to be maximum $(k=1)$ when the total flux in one coil links with the other. The coupled coils are then referred as tightly or perfectly coupled coils. In that case, the mutual inductance between the two coils also reaches maximum with the maximum value of $k$. Moreover, when the two coils are at greater distance in space; the value of $k$ is very small. In this case the two coils are said to be loosely coupled. The value of $k$ varies in the range of 0 to $1 . k$ is a non-negative fraction and has a maximum value of unity. For an iron core coupled coil, the value of $k$ is approximately 0.99 whereas for air core and paramagnetic material the value of $k$ ranges from 0.1 to 0.7. The circuit in Fig. 4 was simulated using the PSPICE software using the component values provided by Table 1, the simulation results are illustrated as follows.

Table 1: Component values of the circuit model

\begin{tabular}{cc}
\hline Component & Values \\
\hline $\mathrm{V}_{1}$ & $25 \mathrm{~V}$ \\
$\mathrm{~V}_{2}$ & $+15 \mathrm{~V}$ \\
$\mathrm{~V}_{3}$ & $-15 \mathrm{~V}$ \\
$\mathrm{R}_{1}$ & $68 \Omega$ \\
$\mathrm{R}_{2}$ & $1 \Omega$ \\
$\mathrm{R}_{3}$ & $1 \mathrm{k} \Omega$ \\
$\mathrm{R}_{4}$ & $10 \mathrm{M} \Omega$ \\
$\mathrm{C}_{1}$ & $1 \mu \mathrm{F}$ \\
$\mathrm{C}_{2}$ & $100 \mathrm{nF}$ \\
\hline
\end{tabular}




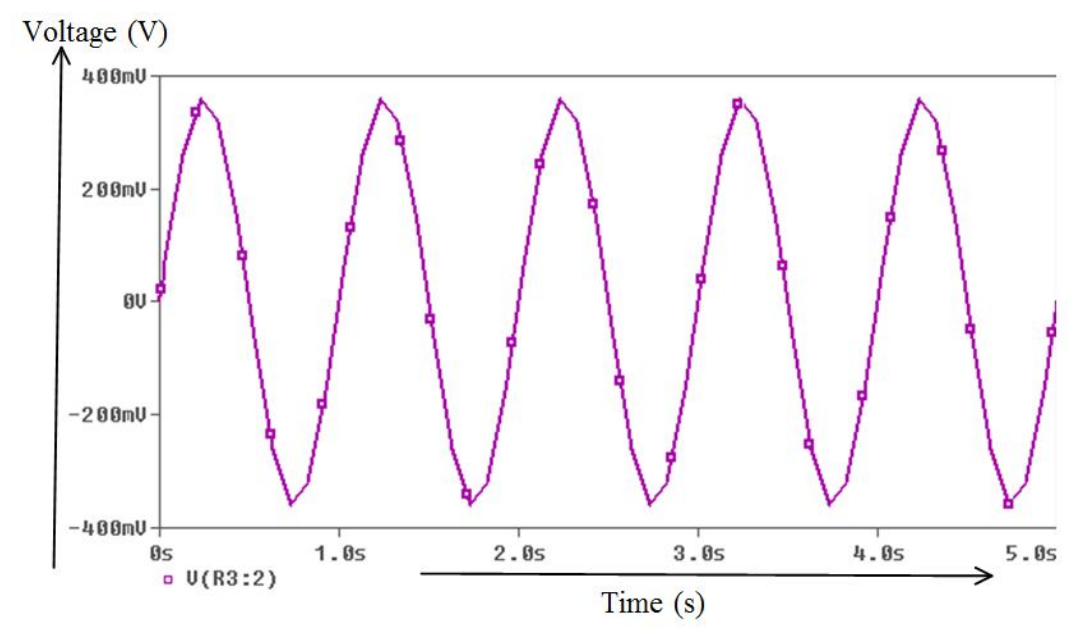

Fig. 5 Input signal of the primary coil.

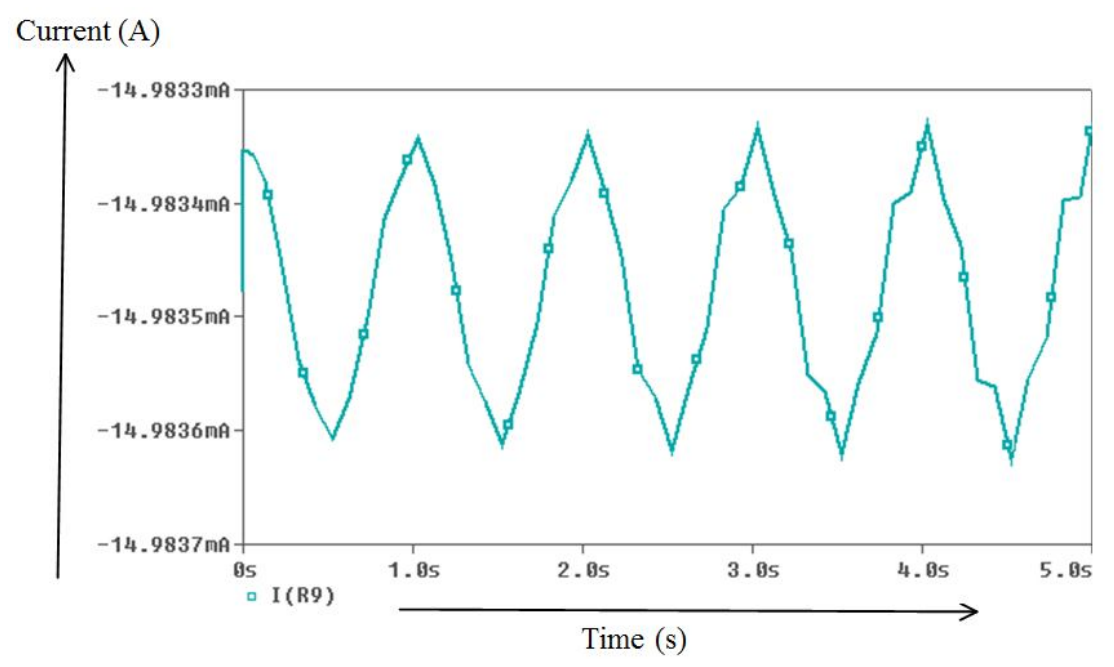

Fig. 6 Output signal at the secondary coil.

Figure 5 shows the input signal, which is the supplied AC current to the primary coil, and the voltage in the secondary windings is illustrated in Fig. 6; both curves are almost true sin waves. The secondary waveform shows some distortion. This is due to core being saturated.

The results demonstrated by Fig. 7 (a) to (c) show B-H curves obtained when the coupling coefficient value is varied for $k=0.99, k=0.6$, and for $k=0.3$, representing the three test materials. The exact coupling coefficient for each material being tested is not known, however the values of $k$ is chosen according to the range the materials fall under.

Figure 7a presents the B-H curve when the coupling coefficient value was set to 0.99 since the iron core is said to have a coupling coefficient of $k=0.99$. Hence it can be said that a soft magnetic core material is simulated. The plot shows low hysteresis loss, indicated by a narrow or 'flat' B-H loop, owing to the theatrical concept of B-H plots of a soft magnetic core material. The maximum saturation point attained is $(373.17 \mathrm{~m}, 1.54)$, 
and minimum saturation point attained is $(-343.6 \mathrm{~m},-1.54)$. For $k=1$ it is considered to be tightly coupled [12] whereas an iron-core is also known to be a tightly coupled coil.

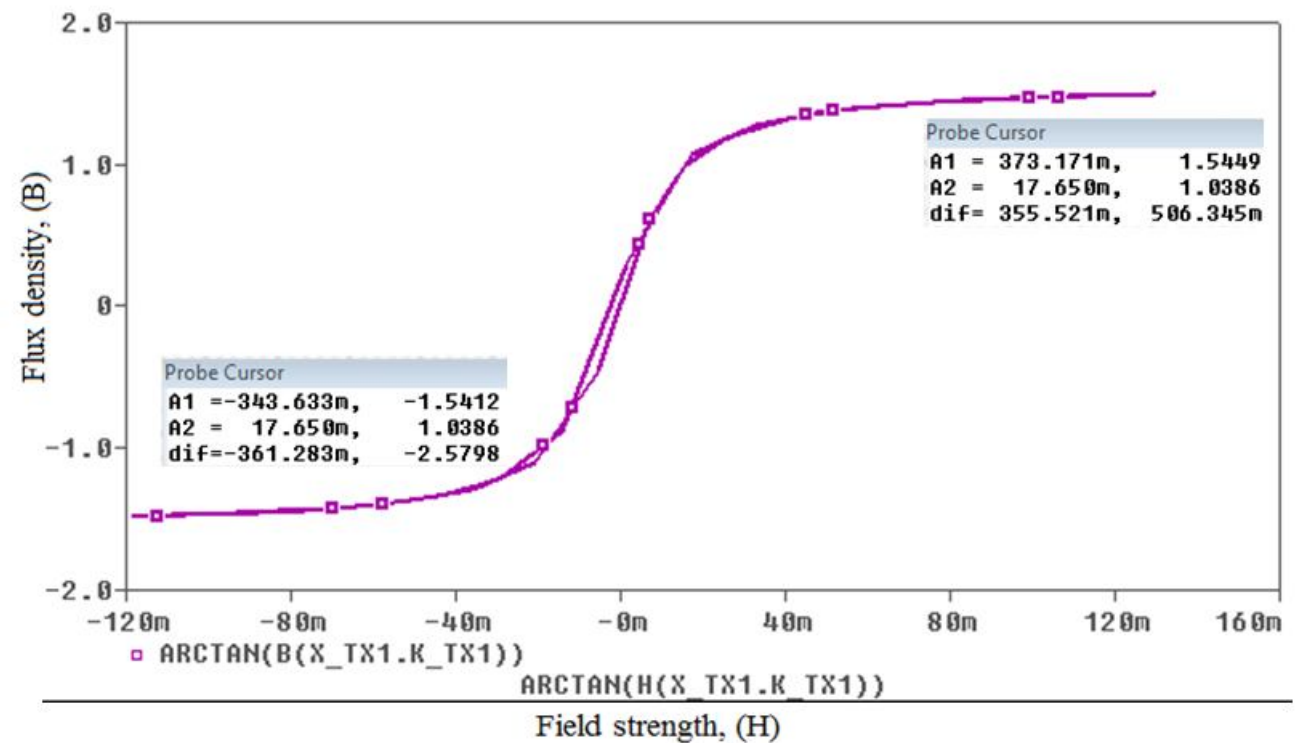

Fig. 7 (a) Hysteresis loop for $k=0.99$.

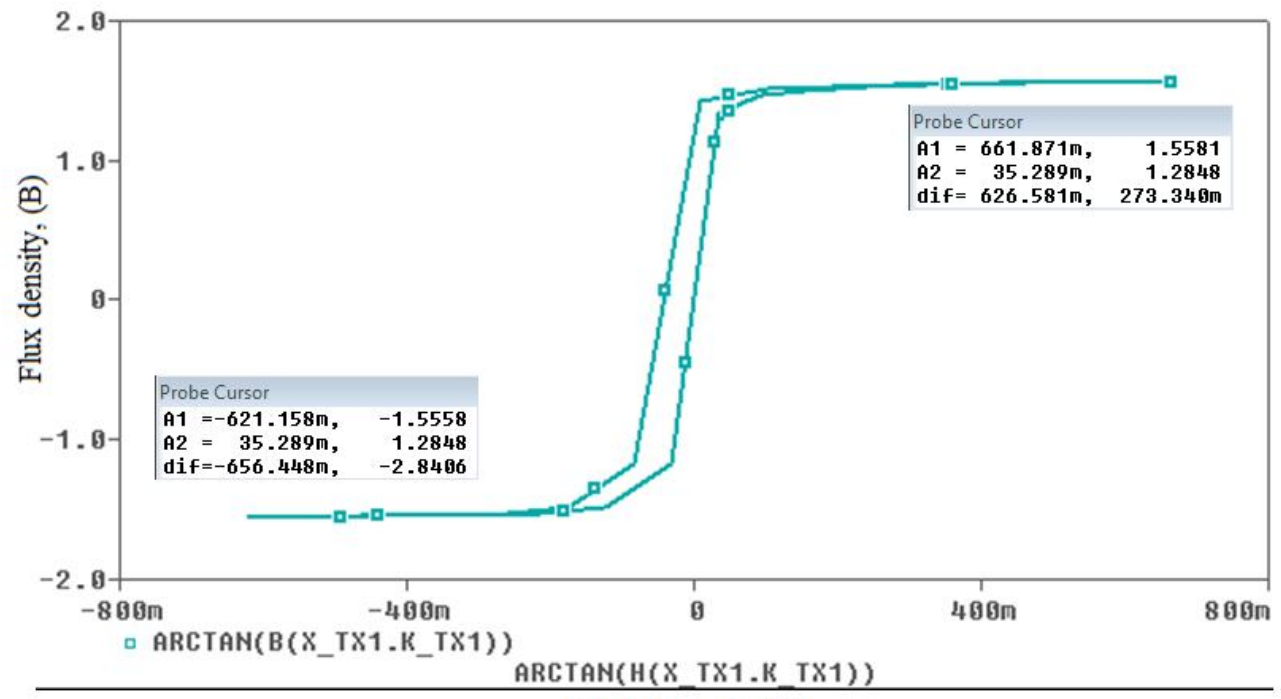

Field strength, $(\mathrm{H})$

Fig. 7 (b) Hysteresis loop for $k=0.6$. 


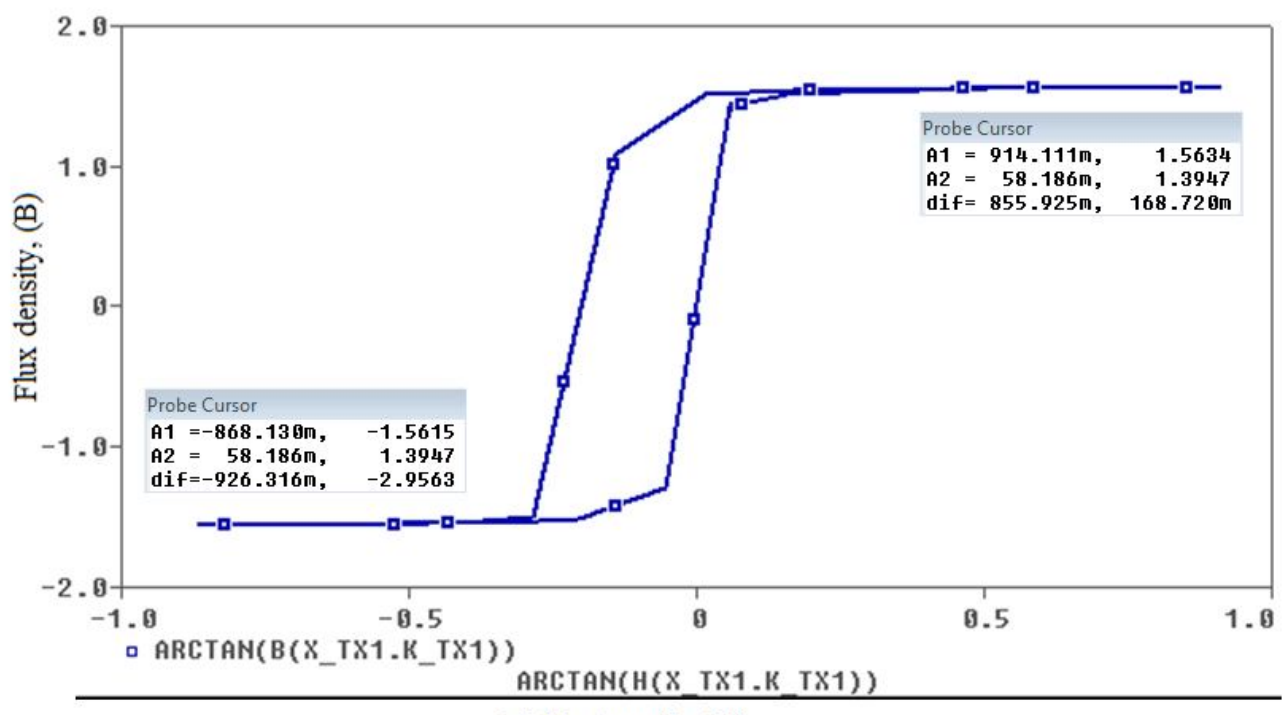

Field strength, $(\mathrm{H})$

Fig. 7 (c) Hysteresis loop for $k=0.3$.

Figure $7 \mathrm{~b}$ shows the B-H curve when the coupling coefficient value was set to 0.6. The maximum and minimum saturation values of magnetism obtained are (661.9 $\mathrm{m}, 1.56)$ and $(-621.16 \mathrm{~m},-1.56)$ respectively. A fairly high hysteresis loss is seen. For a coupling coefficient, ranging between $k=0.4$ to 0.7 is considered to be loosely coupled [12]. Hence the B-H loop curve seems to be broader than the loop compared for $k=0.99$.

In Fig. 7(c), the B-H loop for $k=0.3$ possesses a high value of energy product, thus a high hysteresis loss. This loss can be indicated by the saturation value. Maximum saturation value is $(914.1 \mathrm{~m}, 1.56)$ and the minimum saturation value is $(-868.13 \mathrm{~m},-1.56)$. For air core coupled circuits the coupling coefficient is usually denoted for $k<0.4$ [12].

\subsection{Experimental Analysis to Obtain B-H Loops}

The resulting simulation details are then supported by the laboratory implementation of the circuit in which the core element is made of the actual materials of iron, steel and plastic. The results thus produced are consisting of several sets of B-H curves obtained by using the selected material samples.

The pictorial view of the circuit setup is illustrated in Fig. 8. The equipment used for the experimental setup are; function generator, oscilloscope, voltmeters and cored coils. The results are displayed on the oscilloscope. The oscilloscope was set to work in XY mode to produce the hysteresis loop across the transformer, channel 1 probe (X-axis) of the oscilloscope was set at R2, which measured the voltage across R2 and channel 2 probe (Y-axis) was set at the output of the op-amp $\left(\mathrm{V}_{0}\right)$. The experiment was conducted on three samples; cores of iron, steel and plastic. Table 1 gives the component values used in the construction of the circuit model and Table 2 provides the specification of the coils. 


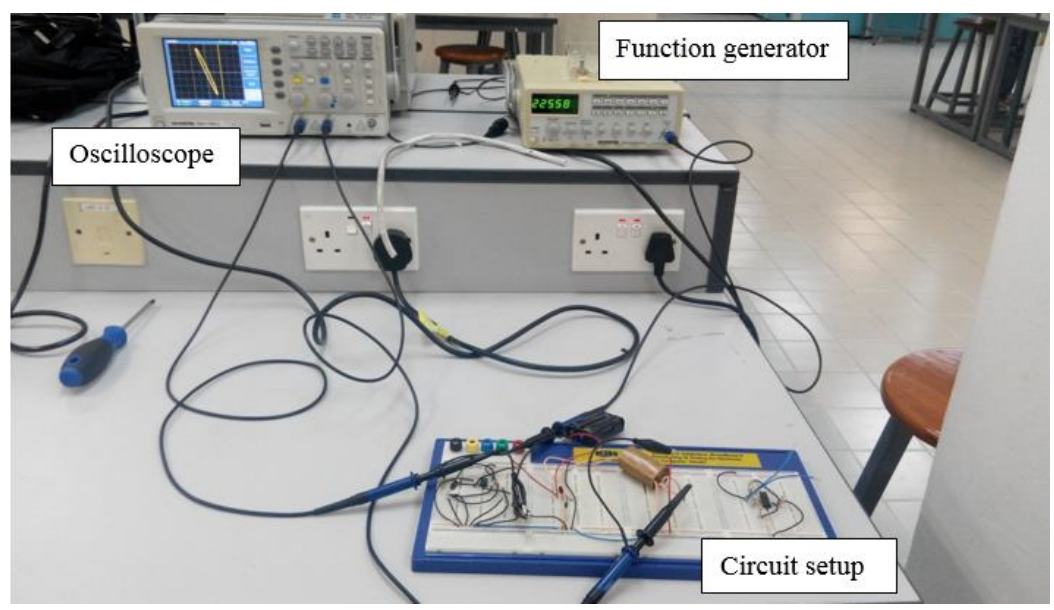

Fig. 8 Pictorial view of the circuit setup for material testing.

Table 2: Specification of coils

\begin{tabular}{l|c}
\hline & Number of Turns \\
\hline Primary coil & 22 \\
Secondary coil & 25 \\
Material of wire: & copper \\
Thickness of wire: & $0.19 \mathrm{~mm}$ \\
Length (mm): & 160 \\
Diameter (mm): & 30 \\
\hline
\end{tabular}

Experimentally the processing for the measurements of flux density, B and field strength, $\mathrm{H}$ signals are obtained for different core materials as shown in Fig. 9. B increases in proportional to $\mathrm{H}$, until it reaches a certain value where it cannot increase further. The increasing strength is the magnetization process and the decreasing portion is the demagnetization process.

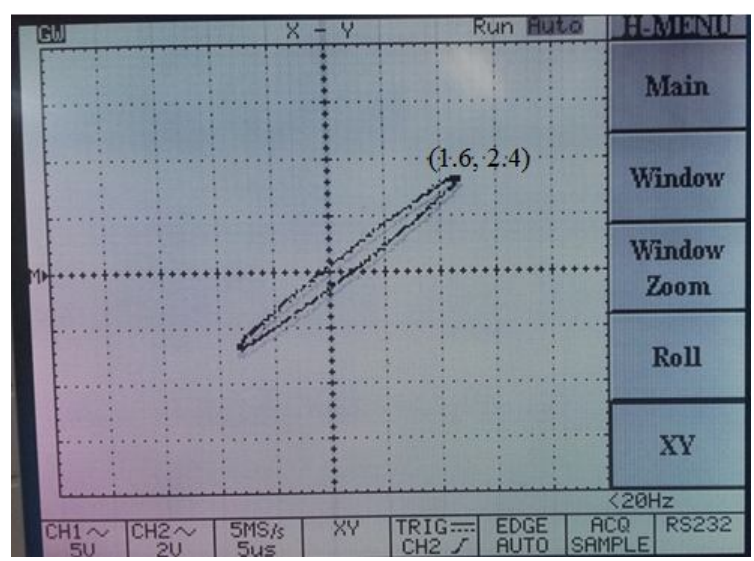

Fig. 9(a) Hysteresis loop obtained using iron-core. 


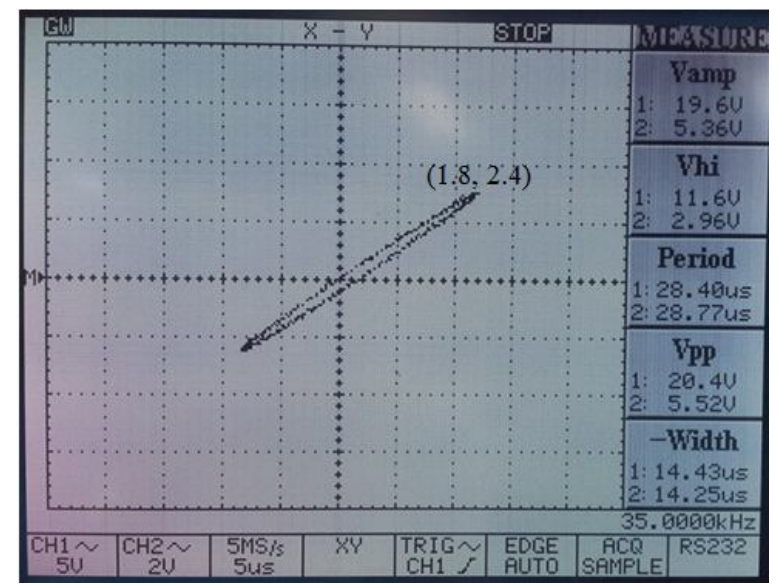

Fig. 9 (b) Hysteresis loop obtained using steel-core.

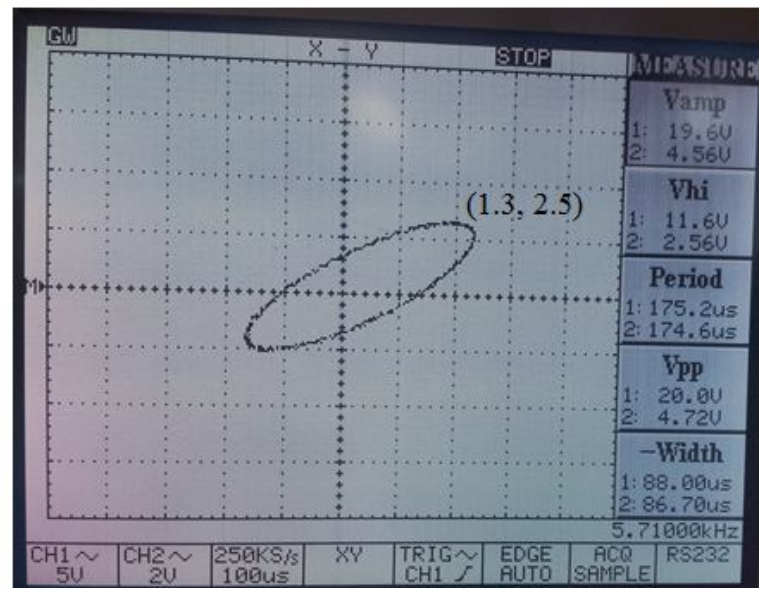

Fig. 9 (c) Hysteresis loop obtained using plastic-core.

Figure 9a demonstrates the hysteresis loop of iron-core with the maximum saturation value of $(1.6,2.4)$. Due to iron being a soft magnetic material, a relatively narrow hysteresis loop is obtained, justifying the simulated result obtained in Fig. 7a.

Figure $9 \mathrm{~b}$ illustrates the hysteresis loop of a steel-core material. The shape of the steel core also shows the loop to be "flat" or narrow owing to the fact that being a soft magnetic material, its hysteresis loop obtained should be "flat". The maximum saturation value noted is $(1.8,2.4)$. The steel core resulted in a smaller coercive force than iron, which is one of the properties of soft magnetic materials. The magnetic saturation is also attained faster with a steel core, compared to an iron core. The set of magnetic hysteresis loop obtained for the iron core showed a larger coercive force, thus attaining its magnetic saturation at a higher magnetic field strength. Moreover the shape of the hysteresis loop depends upon the nature of the iron or steel used, and iron showed considerably large amounts of reversals of magnetism. The various magnetization behaviors of the materials determine their potential applicability for sensing devices.

Figure 9c presents the hysteresis loop obtained experimentally using a plastic-core. Plastic is a non-magnetic material, thus there was no effect on the magnetic field. Plastic core is regarded as a free space, as they have very low values of permeability. Thus plastic is used as a reference core material. The elliptical shape obtained by air-core shows a very good resemblance to the simulated results shown in Fig. 7c. Theoretically/simulated 
results indicate that for an air-core a wide loop should be obtained. Here the maximum saturated valued of $\mathrm{X}-\mathrm{Y}$ is $(1.3,2.5)$.

The simulated results (Fig. 7) showed a good level of resemblance of the experimental result (Fig. 9) obtained, thus justifying the experimental result of the hysteresis loop obtained.

\section{CONCLUSION AND FUTURE WORK}

Magnetic materials, which are essentially used in magnetic sensors, require proper characterization. The characterization of magnetic materials has led towards the use of magnetic biomedical devices along with electromagnetic equipment. The appropriate characterization of magnetic material should be made for the proper choice of materials in specific applications, which is indeed a challenge to any user. This work showed that the widely available simulation tool of PSPICE can reveal the magnetic properties of the materials which are relevant to the experimental study. The change in a material's permeability is represented by the change in the coupling coefficient factor, $k . k$ is inversely proportional to the square root of the product of self-inductance of the coil, that is $k=\sqrt{L_{1} L_{2}}$, and the inductance is influenced by the permeability of the material. With an increase in the value of $k$ the hysterisis loop becomes bigger as well. However, for a soft magnetic material the hysteresis loop graph should be "flat". The simulation output shows low hysteresis loss, indicated by narrow or 'flat' B-H loop, owing to the theatrical concept of B-H plots for a soft magnetic core material. The coupling coefficient value is varied for $k=0.99, k=0.6$, and for $k=0.3$. The change in the materials' permeability is represented by the change in the coupling coefficient factor. $k$ is inversely proportional to the square root of the product of self-inductance, and the inductance is influenced by the permeability of the material. The resulting simulation details are then supported by the laboratory implementation of the circuit in which the core element is made of the actual materials of iron, steel and plastic. With this technique of characterization, the hysteresis model can be implemented easily without using any statistical functions that lead to suitable applications of magnetic materials in biomedical sectors. The novelty lies in applying a simple magnetic sensing circuit for material testing and characterization via obtaining simulation results and validating these results through experiments. To further improve the work, ring shaped core materials can be implemented instead of using hollow solenoid tubes . Ring shaped cores will provide a continuous magnetic path length. Furthermore, when conducting magnetic analyses it is important to determine the magnetic mineralogy, grainsize, and concentration of the various magnetic components within a sample, hence this can be considered in future work.

\section{REFERENCES}

[1] Mokwa W. (2007) Medical implants based on microsystems. Meas. Sci. Technol., 18:R47R57.

[2] Ben Hmida G, Ekuakille AL, Kachouri A, Ghariani H, Trotta A. (2009) Extracting Electric Power from Human Body for Supplying Neural Recording System. Int. J. on Smart and Intelligent Systems, 2(2):229-245.

[3] Gupta AK, Gupta M. (2005) Synthesis and surface engineering of iron oxide nanoparticles for biomedical applications. Biomaterials, 26:3995-4021.

[4] Huo X, Wang J, Ghovanloo M. (2008). A magneto-inductive sensor based wireless tonguecomputer interface. IEEE Trans. on Neural Sys. Rehab. Eng., 16(5):497-504. 
[5] Safarik I, Safarikova M. (2002) Magnetic nanoparticles and biosciences. Monatshefte fur Chemie, 133(6):737-759.

[6] Shinkai M. (2002). Functional magnetic materials for medical applications. J. of Bioscience Bioeng., 94: 606-613.

[7] Bahadur D, Giri J. (2003) Biomaterials and magnetism. Sadhana, 28:639-656.

[8] Pankhurst QA, Connolly J, Jones SK, Dobson J. (2003) Applications of magnetic nanoparticlesin biomedicine. J. of Physics D: Applied physics, 36:167-181.

[9] Markham A, Niki T, Stephen A, David W. (2010) Revealing the hidden lives of underground animals using magneto-inductive tracking. Proceedings of the 8th ACM Conference on Embedded Networked Sensor Systems, 281-294.

[10] O'Handley, RC. (2000) Modern magnetic materials principles and application, WileyInterscience.

[11] James WN, Susan AR. (2004)Electric Circuit, 7th Edition, Prentice Hall.

[12] Sadiku MNO, Alexander CK. (2009) Fundamentals of electric circuits,4th Edition. McGraw Hill. 